\title{
Reply: Tumour and normal cells differ in the induction and repair of DNA double-strand breaks
}

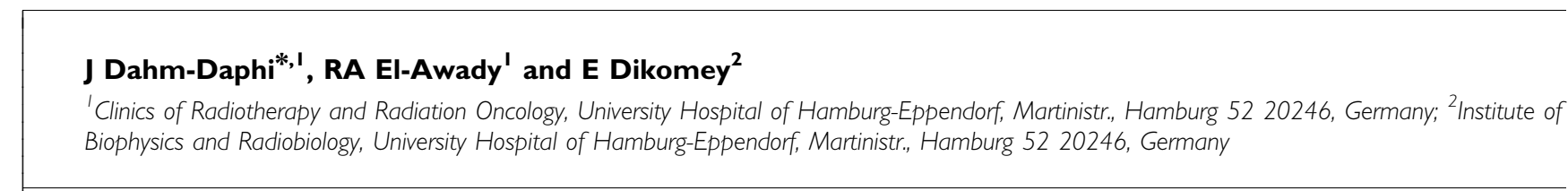

British Journal of Cancer (2004) 90, 556. doi:I0.1038/sj.bjc.660I573 www.bjcancer.com

(c) 2004 Cancer Research UK

Sir,

The authors acknowledge the comments advanced by Dr Böhm. A major concern was about the seemingly disparate results presented in our studies (Dikomey et al, 1998, 2000; El-Awady et al, 2003). We lastly described (El-Awady et al, 2003) that tumour cells significantly differ in the number of radiation-induced dsb. As outlined (El-Awady et al, 2003), there is also sufficient evidence for that in the literature. We further found that this difference is correlated with the respective radiosensitivity. In contrast, fibroblasts showed identical numbers of induced dsb and, consequently, survival cannot be correlated with dsb induction (Dikomey et al, 1998, 2000; El-Awady et al, 2003). On the other hand, fibroblasts showed different repair capacities, which were then associated with the variation in cellular sensitivity (Dikomey et al, 1998, 2000). No such correlations were found for the tumour strains, and we provided evidence that this is at least partly due to the fact that the measurement of residual dsbs is perturbed by cell cycle effects and apoptosis, which cannot be separated from dsb repair kinetics.

Two points can be extracted from this. (1) There are significant differences between normal and tumour cells in the variation of dsb induction. (2) Standard gel electrophoresis is suitable to determine dsb induction in both tumour and normal cells, but repair capacity can only be determined in normal cells (fibro-

\section{REFERENCES}

Böhnke A, Westphal F, Schmidt A, Dahm-Daphi J (2004) The role of p53 mutations, protein function and DNA damage for the radiosensitivity of human tumour cells. Int J Radiat Biol, in press

Dikomey E, Dahm-Daphi J, Brammer I, Martensen R, Kaina B (1998) Correlation between cellular radiosensitivity and non-repaired doublestrand breaks studied in nine mammalian cell lines. Int J Radiat Biol 73: $269-278$ blasts). This, however, does not mean that the dsb repair capacity is not relevant for the cellular radiosensitivity of tumour cells. To our best knowledge, there are no appropriate methods at hand, for several reasons not even recording of $\gamma-\mathrm{H} 2 \mathrm{AX}$ foci, to measure dsb repair in tumour cells.

The differences in dsb induction among tumour cell lines is likely to be explained by variation in their chromatin structure and thus in their protective capacity from DNA damage, while normal cells maintain a constant chromatin structure. This is supported by many recent results emphasising variant patterns of chromatin methylation and histone acetylation in tumour cells. Moreover, the p53 status which is described in a second paper (Böhnke et al, 2003) also suggests that p53 could possibly influence the chromatin and hence the amount of induced damage. Those factors may not apply for differentiated normal cells and thus the number of induced DNA damages appears to be fairly constant.

In conclusion, we feel that the data presented are consistent rather than contradictory, as claimed by Dr Böhm. Nevertheless, we agree with the comment that some preceding data should be reviewed again in the light of the recent results. And, secondly, we fully agree that additional factors besides DNA dsb could well (co-)determine the cellular response to radiation, whereby micronuclei and apoptosis, as brought forward by Dr Bohm, may well be the consequence of dsb.
Dikomey E, Brammer I, Johansen J, Bentzen SM, Overgaard J (2000) Relationship between DNA double-strand breaks, cell killing, and fibrosis studied in confluent skin fibroblasts derived from breast cancer patients. Int J Radiat Oncol Biol Phys 40: 481-490

El-Awady RA, Dikomey E, Dahm-Daphi J (2003) Radiosensitivity of human tumour cells is associated with the induction but not with the repair of DNA double-strand breaks. Br J Cancer 89: 593-601 